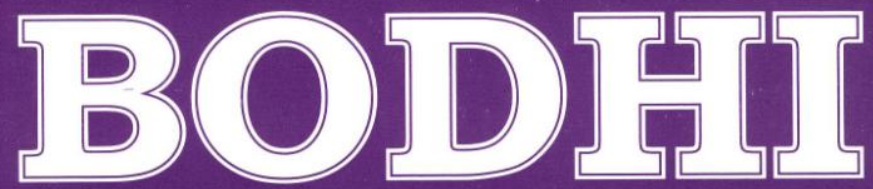

An Interdisciplinary Journal

ISSN: 2091-0479

Department of Languages and Mass Communication School of Arts

Kathmandu University

Bodhi, 4 (1), 191-197. ISSN 2091-0479. (C) 2010 Kathmandu University 


\section{Language as a way of shaping our identity, idea and action}

- Rebati Prasad Neupane

Language is the most effective means of human communication. It uses symbols to which the users give the meanings. We use language to communicate our thoughts, feelings, intentions, attitudes and desires to others. So, language is essentially a communal possession for communication between different people who share that language. It cannot exist unless it becomes common to the whole community. "We learn about people through what they say and how they say it; we learn about ourselves through the ways that other people react to what we say" (Bonvillain, 2000, p. 1). We use it to communicate through our lives from home to school, from school to work, from childhood to maturity and through friendship, jobs and marriage. It helps us to develop and maintain everything around us (Montgomery, 1995, p xxi). It is through the language that we start reasoning. It is what makes us fully human. However, language is much more than simply a means of verbal communication. So, in this article, I argue that language has the power of shaping who we are, what we know and what we do.

Language is an expression of who we are. It is more a strong indicator of identity than those of cultural artifacts such as food, dress, choices and manners. For instance, there are some words in one language which may not be found in the other language. So the language and culture have ideas that don't exit in the other language and culture. When we think over a certain thing we think in Nepali but when Spanish thinks over an issue, he thinks in Spanish. Our sentences are differently structured from Spanish. The thought process of Spanish is different from ours. In that sense language determines identity. Let us take another instance. Hindi is the language spoken by the Indians and Danish is how Danes speak. Language can also be taken as 
different ways of talking about social background, education, profession, age and sex. A cockney flower girl does not speak the same language as Professor Higgins does even though English is the common mother tongue. They speak differently because they come from different social worlds.

When we use language we are revealing our social worlds, our professions and identities to others. The way the other person interacts with us also shapes the image we have of ourselves. For instance, if parents often criticize their children as naughty ones, they will grow up with little confidence and lose their ability to do things. The minister who gives sermon in the Prayer affects his audience. The way an audience is enlightened shapes the image of his own. Thus how others respond to our behavior and activities affects and shapes our identity. In a sense, it is a kind of imposed communication that shapes someone's identity. Stuart Hall, a scholar working within Cultural Studies, explains that we act out our identities in the ways we address the others. To Stuart Hall, this way of imposing identities through address, whether verbal or nonverbal, interpersonal or visual, is a hailing. Hailing restricts around who we become. In the past women were hailed as only providers but now they are hailed not only as providers but also home makers (Hall 108). For instance, we may hail one of our friends as romantic, athletic, up-to-date, active and honest. Doing so, we are imposing his identity on the basis of what image we have made of him. Our parents may hail one another as mother and parents rather than the lovers. In fact, we might be doing something wrong by imposing identity on those whom we know and care about most by using a limited number of ways of hailing.

Hailing is a concept that explains the link between ideologies and identities. When a person is ready to be hailed in particular way he tacitly accepts the world view/ideology. Ideologies are powerful because they become the unquestioned basis for so much of our thought and action. The dominant culture produces ideologies, as Marx views, to undermine competing cultures. 
Ideologies are recurrent system of meanings. For instance, an adult hails a child, the child answers, now a conversation follows. The act of participating in the conversation includes ideologies into our social systems. In this case the ideology reestablishes the child as powerless, innocent, and nonsexual. The adult is all knowing and all powerful. The process by which communication positions people in ideologies is known as interpellation. Hailing and interpellation are the different phase of the same process.

If caring is hailing, ignoring is also a form of hailing that constricts an identity. For instance, the ones who are bisexual or gay are usually ignored by the society. Such persons who feel humiliated in social relation experience marginalized sexual identities. It follows that communication that shapes identities also creates and maintains cultures within our society. Clifford Greetz, an anthropologist, links culture and communication by arguing that culture transmits the historically patterned social meanings through language (symbols) (1973, p. 89). Now it is obvious that culture is a constant process of producing meanings from our social experience and such meanings necessarily produce a social identity for the people. Communication and culture are inseparable in that they come together in systems of meaning that shape our identity.

Language also shapes the idea/knowing in the way it shapes the identity. Language is a sign that signifies a concept, which Ferdinand Saussure terms as signifier. The signifier refers to anything including words, objects, animals, colors, tastes, trees and so on. Language as a system of signs is studied scientifically which is known as semiotics. The Semiotics allows no structure to put the boundaries around ideas. Rather, it draws relationship among ideas. The semiotics ignores the boundaries of symbolic-verbal communication and studies all kinds of meaning. Sound, images, gestures, actors, dialogue, lighting, and editing are signifiers for semiotic interpretation. The semiotics casts language in different frames. The semiotics offers possibilities to go beyond the meaningful communication 
for many other referential meanings of the language. "A semiotic approach displaces the question of how words correspond to the world, by focusing on meaning as mental process" (Gottdiener, 1995, p. 11). The semiotics framework imagines meaning as a process in which the signifiers join the signfieds. The signifiers become meaningful signs when people associate them with the concept known as the signified. For example, the obese of the wrestler is the signifier for his vileness; cleanliness can be a signifier of feminine identity in American culture. One sign relationship, such as cleanliness signifying feminity or the obese signifying vileness is only a microscopic part of the meaning process. Signs combine themselves with other signs into systems of meaning or ideologies. The language takes us beyond the perceptual level to the conceptual thought processes. For instance, the phrase consisting of the signifiers "This girl is vey tall" at first glance seems clear and specific but it generates more than one thought. When the speaker says that "This girl is vey tall" it signifies that there is only one girl who is tall in a particular settlement. It may also be signifying that the speaker is comparing the girl to himself/herself. Is the speaker surprised by her height? Or is the speaker merely informing that the girl is very tall? Does the speaker think that we need such information? Is she being sarcastic? This string of questions suggests that it is the language that forms ideas about the world.

Analogous to semiotics, metaphors expresses meanings through complex process of semantic extension and transfer. Metaphor is a comparison between entities or events that share certain common features. The comparison implicitly highlights similarities while ignoring contrasts. Lakoff and Mark Johnson in Metaphor We Live By stress that "the essence of metaphor is understanding and experiencing one kind of thing in terms of another"(1980, p. 35). These writers identify metaphors as cognitive and intellectual process. The metaphor is a process of moving from one idea to another in which people invent or discover ideas and ideologies. Edwin Black sees the ideology in "communism in cancer" metaphor, which was popular 
especially among right-wing politicians during the cold war. He sketches out the American view of cancer which he uses to discuss communism. Cancer's attack centers on the inner part of body; it grows, spreads and eventually leads someone to death. (qtd. in Cohen, 1998, p. 44) The "communism in cancer" metaphor generates the idea that communism is a kind of cancer that eventually leads the nation to destruction just like cancer leads someone to death. This metaphor does not limit us to a single denotative meaning. It makes us think that this metaphor is used to disseminate anticommunist feelings. It is raising a question about the effectiveness communism as a system of politics. Or the rulers themselves are cancerous. This metaphoric use of language opens a venue for several other ideas.

Metaphors in a language reveal underlying concepts that help construct the reality or world view of the speaker. The analysis of metaphor shows that all kinds of experiences of men in society are cultural. We experience our world in such a way that our culture is already present in the very experience itself. Lakoff and Johnson argue that analysis of metaphor provides insight into cultural construction of reality because "our ordinary conceptual system in terms of which we both think and act is fundamentally metaphorical in nature" (1980. p. 3).

Just like language shapes identity and idea, it shapes action as well. For example, in Athens public communication was regarded as most essential for democracy and democratic practices. In order to form democratic polices and legal decision, persuasion was given much priority. It is through rhetoric, or persuasive communication, the public formed social action. Similarly, Michael Leff"s study of Lincoln's Second Inaugural Speech Address reflects how his language style directed the perception of the Civil War and shaped postwar policy. In his Speech Lincoln makes the sense of war in a way that would allow the country to reunite and rebuild. His use of language frames the war as if it is merely a divine intervention. His choice of verb tense, arrangement of sentences and 
paragraphs, tone, and imagery construct the public as passive and forgiving being (qtd. in Cohen, 1998, p. 36). In his speech he maintains his switches from past tense to present tense and present to the future tense. As he moves from past to present, he uses an increasing number of religious imagery by quoting the Bible and referring to the Prayer. His speech pushes the audience to mold the future in the frame of the Christian virtues. Such a clear and effective style is often aided by method of amplification - word choices and word arrangements that enliven ideas.

Human life is the storehouse of experiences. A man in his life experiences not only hardship, problems, failure and misfortune but also ecstasy, abundance and success. So life is the blend of both happiness and sorrow. In the course of life, man makes his own identity, shapes his ideas about the world and set direction for his work. In other words, our lives consist of who we are, what we think and what we do. These three things - our identities, our ideas and our actions - can exist only through meaningful communication. Semiotic approaches of language that take us to the conceptual level of thought from perceptual one are valuable for unraveling the ways signifiers shape our ideas, identities and work to be done.

\section{References}

Bonvillain, Nancy. (2000) Language, Culture and Communication. $3^{\text {rd }}$ ed. New Jersey: Prentice Hall.

Cohen, Jodi R. (1998) Communication Criticism. London: SAGE Publications.

Greetz, Clifford. (1973) Interpretation of Culture. New York: Basic Books.

Gottdiener, M. (1995) Postmodern Semiotics:the material culture and the forms of postmodern life. Cambridge: Blackwell.

Hall, Stuart. (1985) "Signification, representation, ideology, Althusser and the post structuralist debate." Critical 
Studies in Mass Communication. Oxford: Oxford University Press. 91-114.

Lakoff, George and Mark Johnson. (1980) Metaphors We Live By. Chicago: University of Chicago Press.

Montgomery, Martin. (1995) An Introduction to Language and Society. London and New York: Routledge.

Dr. Neupane is Associate Professor at the Central Department of English, Tribhuvan University, Kritipur, Kathmandu. 